\title{
EDITORIAL: Corporate law and governance fundamental issues and peculiarities
}

Dear readers!

We are pleased to present the first issue of the journal introduced in 2019.

The first issue of the journal "Corporate Law \& Governance Review" is devoted to the issues of convergence of corporate governance towards intrinsic value, the impact of 4.0. innovation and regulations in the labour market, the effects of law and regulation on Italian corporate board practices in Italy and the board specificities in listed Portuguese firms.

In the study "Evolution of corporate governance towards intrinsic value" the authors analyse the traditional shareholder versus stakeholder focus, contributing to the previous research by Grove and Clouse (2018), Apreda (2006), Donaldson and Preston (1995), Evan and Freeman (1983) and explaining how we can move towards the more comprehensive stakeholder approach, exploiting fundamental analysis as a value driving pattern. The classic trade-off between market value and intrinsic (fundamental) value is considered with a technological approach nurtured by artificial intelligence.

Innovation is the inspiring driver of another paper about the impact of Industry 4.0. on the Italian labour market. The effect that technology has on key stakeholders represented by employees is currently under investigated despite the research undertaken by Blair and Roe (1999), Westphal and Zajac (1998), Hunter (1998), Lewis, Machold, Oxtoby, Ahmed (2004). In particular, corporate governance literature has seldom considered the implications of technology on new and old professions that reshape the internal organization of the firm, with deep governance consequences. Trade unions represent an external stakeholder, linked to affiliated employees, and they representation within the firm is deeply affected by the governance implications of unprecedented innovation. The Italian case is considered as a living lab, with geographical analogies applicable to other industrialized countries.

The labour market in the U.S. is analyzed in a further study that considers another under investigated topic, concerning new educational requirements for childcare workers. Regulations pertaining to childcare workers' qualifications and staff-child ratio affecting the childcare market in the District of Columbia are analyzed. Working mothers represent a key stakeholder, again under investigated by traditional corporate governance, and this paper fills a gap in the literature, considering the impact of legislation on these sensitive issues.

Board models are the inspiring source of two other papers that consider, respectively, the impact of law and regulations on corporate board composition and working in Italy, or the Two-Tier model applied by the majority of listed Portuguese firms. This paper contributes remarkably to the previous papers by Sahore and Verma (2019), Basyith, Fauzi and Idris (2015), Giovinco (2014), Guerra, Fischmann, and Machado Filho (2008), Kostyuk (2005).

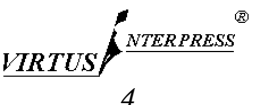


The study focused on Italy considers the impact of corporate board models under the classic/traditional, dualistic or monistic system, where directors and statutory auditors interact in different ways. Gender issues reshape the board composition and represent a complementary trendy issue in the governance debate, in Italy and abroad. Previous research in the Italian context of corporate governance by Napoli (2019), Rizzato, Busso, Devalle, and Zerbetto (2018), Colli (2009) and international context too by Zeitun (2009), Rogers, Dami, de Sousa Ribeiro, and de Sousa (2008), can be taken for a solid fundament for this paper.

Portuguese listed firms show specificities in the composition of the board, showing that executive members still prevail over non-executives. Gender issues are considered also in Portugal, with limited representation of women in the boardroom. International best practices that have long debated over these issues may represent a model for catching up countries (Chidiac El Hajj, 2018; John \& Senbet, 1998).

Roberto Moro Visconti, Professor, Catholic University of the Sacred Heart, Italy Co-Editor-in-Chief, Corporate Law and Governance Review

\section{REFERENCES}

1. Apreda, R. (2006). The semantics of governance: The common thread running through corporate, public, and global governance. Corporate Ownership \& Control, 3(2), 45-53. http://doi.org/10.22495/cocv3i2p6

2. Basyith, A., Fauzi, F., \& Idris, M. (2015). The impact of board structure and ownership structure on firm performance: An evidence from blue chip firms listed in Indonesian stock exchange. Corporate Ownership \& Control, 12(4-3), 344-351. http://doi.org/10.22495/cocv12i4c3p2

3. Blair, M. M., \& Roe, M. J. (1999). Employees and corporate governance. Brookings Institution, Washington, DC.

4. Basuony, M. A. K., \& Mohamed, E. K. A. (2014). Board composition, ownership concentration, and voluntary internet disclosure by MSM-listed companies. Corporate Board: Role, Duties and Composition, 10(1), 60-70. http://doi.org/10.22495/cbv10i1art5

5. Chidiac El Hajj, M. (2018). A closer look at the corporate governance in Lebanon: A call for a bottom-up reform. Corporate Governance and Sustainability Review, 2(2), 48-61. http://doi.org/10.22495/cgsrv2i2p5

6. Colli, A. (2009). A tale of lost chances. A short history of corporate governance and ownership in Italy. Corporate Ownership \& Control, 7(1-2), 265-273. http://doi.org/10.22495/cocv7ilc2p2

7. Donaldson, T., \& Preston, L. (1995). The stakeholder theory of the corporation: Concepts, evidence and implications. Academy of Management Review, 20(1), 65-91. https://doi.org/10.5465/ amr.1995.9503271992

8. Evan, W., \& Freeman, R. E. (1983). A stakeholder theory of the modern corporation: Kantian capitalism. In T. Beauchamps, \& N. Bowie, (Eds), Ethical Theory and Business (pp. 75-93). Prentice Hall, Englewood Cliffs, NJ.

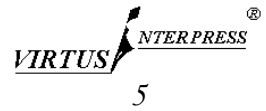


9. Giovinco, A. (2014). Gender diversity in the boardroom. Context and Spanish case. Corporate Board: Role, Duties and Composition, 10(3), 60-76. http://doi.org/10.22495/cbv10i3art5

10. Grove, H., \& Clouse, M. (2018). Focusing on sustainability to strengthen corporate governance. Corporate Governance and Sustainability Review, 2(2), 38-47. http://doi.org/10.22495/cgsrv2i2p4

11. Guerra, S., Fischmann, A., \& Machado Filho, C. A. P. (2008). An agenda for board research. Corporate Board: Role, Duties and Composition, 4(1), 50-56. http://doi.org/10.22495/cbv4ilart4

12. Hunter, L. (1998). Can strategic participation be institutionalised? Union representation on American corporate boards. Industrial and Labour Relations Review, 51(4), 557-578. https://doi.org/10.1177/001979399805100401

13. John, K., \& Senbet, L. W. (1998). Corporate governance and board effectiveness. Journal of Banking and Finance, 22, 371-403. https://doi.org/10.1016/S0378-4266(98)00005-3

14. Kostyuk, A. N. (2005). Board committee practices in Ukraine. Corporate Ownership \& Control, 3(1), 114-116. http://doi.org/10.22495/cocv3i1p10

15. Lewis, T. L., Machold, S., Oxtoby, D., \& Ahmed, P. K. (2004). Employee roles in governance: Contrasting the UK and German experience. Corporate Governance: The international journal of business in society, 4(4), 16-28, https://doi.org/10.1108/1472700410558853

16. Napoli, F. (2019). Measuring the efficacy of board governance: Empirical evidence from Italian publicly listed companies. Corporate Ownership \& Control, 16(2), 25-37. http://doi.org/10.22495/cocv16i2art3

17. Rizzato, F., Busso, D., Devalle, A., \& Zerbetto, A. (2018). Corporate governance system in Italy: Compliance and quality. Corporate Ownership \& Control, 16(1-1), 217-233. http://doi.org/10.22495/cocv16i1c1art9

18. Rogers, P., Dami, A. B. T., de Sousa Ribeiro, K. C., \& de Sousa, A. F. (2008). Corporate governance and ownership structure in Brazil: causes and consequences. Corporate Ownership \& Control, 5(2), 36-54. http://doi.org/10.22495/cocv5i2p4

19. Sahore, N. S., \& Verma, A. (2019). Corporate voluntary disclosures and board independence of Indian companies. Corporate Governance and Sustainability Review, 3(1), 42-50. http://doi.org/10.22495/cgsrv3i1p4

20. Westphal, J., \& Zajac, E. (1998). The symbolic management of stockholders: Corporate governance reforms and shareholder reactions. Administrative Science Quarterly, 43, 127-153. https://doi.org/ $10.2307 / 2393593$

21. Zeitun, R. (2009). Ownership structure, corporate performance and failure: Evidence from panel data of emerging market the case of Jordan. Corporate Ownership \& Control, 6(4), 96-114. http://doi.org/10.22495/cocv6i4p10

22. Shan, Y. G., \& Taylor, D. W. (2008). Related-party disclosures in the two-tier board system in China: Influences of ownership structure and board composition. Corporate Board: Role, Duties and Composition, 4(1), 37-49. http://doi.org/10.22495/cbv4i1art3 